\title{
A study of plasma copeptin level as a predictor of severity during acute exacerbation of bronchial asthma
} Ahmed G. El Gazzar ${ }^{\mathrm{a}}$, Khaled M. Belal ${ }^{\mathrm{b}}$, Tarek S. Essawy ${ }^{\mathrm{a}}$, Neveen M. Abd-Elfattah ${ }^{\mathrm{a}}$

\begin{abstract}
Background An exacerbation of asthma is an episode, characterized by a progressive increase in one or more typical asthma symptoms (shortness of breath, wheezing, cough, and chest tightness).

Copeptin is a 39-amino acid glycopeptide that is derived from the c-terminal part of the pre-pro-hormone of arginine vasopressin.
\end{abstract}

Aim The aim of our study was to evaluate the role of copeptin in asthmatic patients and its relationship to disease severity.

Patients and methods This was a prospective observational study carried out on 45 patients during acute exacerbation of bronchial asthma (15 mild, 15 moderate, and 15 severe cases) and 15 healthy participants.

Results Our study showed no significant difference in age, sex, and BMI between case and control groups. There was a statistical highly significant differences in pulmonary function tests, partial pressure of oxygen in arterial blood, partial pressure of carbon dioxide in arterial blood, and oxygen saturation among mild, moderate, and severe cases, and significant increase in total leukocytic count and hospital stay in severe cases than mild and moderate cases. There was a highly significant increase of plasma copeptin in moderate and severe cases than mild cases and control groups. There were nonsignificant correlations between copeptin and pulmonary function tests in mild cases; a significant negative

\section{Introduction}

Asthma is defined as a common lung inflammatory disorder of the airways that causes the bronchi to swell; this results in difficulties of breathing, chest tightness, cough, and wheezing. Severe exacerbation of bronchial asthma was defined as a life-threatening condition that should be managed as an emergency, and patients need hospital admission owing to worsening asthma, need for systemic corticosteroids, or morning peak flow decrease more than $25 \%$ of baseline in two successive days [1].

Copeptin, a 39-amino acid glycopeptide, is a carboxyterminal part of the precursor (pre-pro-vasopressin). Vasopressin has an antidiuretic action on kidney so it is termed antidiuretic hormone. It is involved in renal and cardiovascular functions [2].

Xue et al. [3] evaluated the prognosis of copeptin utility in 525 patients who have acute dyspnea owing to asthma. They found that copeptin was a significant independent predictor of prolonged hospital stay and mortality in patients who have acute dyspnea owing to bronchial asthma. correlation between copeptin and forced expiratory volume in 1s (FEV1) actual in moderate cases; significant negative correlations between copeptin, FEV1 actual, FEV1\% predicted, forced vital capacity $\%$ predicted, and peak expiratory flow\% predicted in severe cases; and highly significant negative correlations between copeptin and partial pressure of oxygen in arterial blood and oxygen saturation in all cases $(P<0.001)$. Partial pressure of carbon dioxide in arterial blood exhibited a nonsignificant positive correlation with copeptin $(P<0.05)$.

Conclusion Copeptin is proven to be a novel biomarker and is increased in patients with asthma as compared with healthy controls.

Egypt J Bronchol 2019 13:443-451

(C) 2019 Egyptian Journal of Bronchology

Egyptian Journal of Bronchology 2019 13:443-451

Keywords: acute exacerbation, asthma, copeptin

${ }^{a}$ Department of Chest Diseases, ${ }^{b}$ Department of Clinical and Chemical Pathology, Benha University, Benha, Egypt

Correspondence to Neveen M. Abd-Elfattah, MSc, Benha, Egypt. Tel: +20 100027 1189;

e-mail: drneveenmohsen@gmail.com

Received: 8 August 2018 Revised: 21 January 2019

Accepted: 2 February 2019 Published: 25 October 2019

\section{Aim}

The aim of this study is to measure the level of plasma copeptin during acute exacerbation of bronchial asthma to determine if there is a change in its level that correlates with changes in the ventilatory functions.

\section{Patients and methods}

\section{Patients}

This was a prospective observational study carried out on 60 patients at Benha University Hospital Chest Department. They were classified into four groups: control group comprised 15 apparently healthy nonsmoker patients, and asthma group comprised 45 patients (15 mild cases, 15 moderate cases, and 15 severe cases), classified according to Global Initiative for Asthma 2016 guidelines [4].

This is an open access journal, and articles are distributed under the terms of the Creative Commons Attribution-NonCommercial-ShareAlike 4.0 License, which allows others to remix, tweak, and build upon the work non-commercially, as long as appropriate credit is given and the new creations are licensed under the identical terms. 


\section{Inclusion criteria}

Patients during acute exacerbation of bronchial asthma, admitted to inpatient Chest Department, Benha University Hospital, were included.

\section{Exclusion criteria}

In our study, we excluded patients who have renal impairment, patients of chronic obstructive pulmonary disease (COPD), patients of cardiac asthma, and pregnant female.

\section{Methods}

All participants were subjected to the following:

(1) Full clinical history: some features strongly support the diagnosis of asthma such as nocturnal attack, periodicity of symptoms, and diurnal and seasonal variations. Symptoms resulting owing to exertion, allergen exposure, and presence of atop in the patient or his/her family also support the diagnosis. Patients were also asked about duration of the disease, previous hospital admission, the therapy needed to control the symptoms, the family history, and history of other allergies such as skin or nasal allergy.

(2) Clinical examination (general and local chest) revealed signs of airway obstruction.

(3) Plain chest radiography lateral and posteroanterior views to exclude any associated radiological abnormality.

(4) Complete blood count for determination of total and differential leukocytic counts.

(5) Pulmonary function tests using JAEFER MSPFT by Care Fusion (Germany). Was performed after administration of bronchodilators, 6-8 h after stability of patient's acute asthma exacerbation.

(6) Arterial blood gases analysis using Sensa Core Medical Instrumentation Pvt Ltd (India).

(7) Measurement of copeptin levels: $\sim 2.5-5 \mathrm{ml}$ of blood samples was taken from patients in test tubes containing EDTA as an anticoagulant. Centrifugation of the samples for $15 \mathrm{~min}$ at $1000 \mathrm{~g}$ within $30 \mathrm{~min}$ of collection was done, and samples were stored in aliquots at -20 to $-80^{\circ} \mathrm{C}$ until the time of measurement. To determine plasma copeptin concentration samples, a new sandwich immuneluminometric assay was used. In brief, the EDTA plasma samples were incubated with antibodies diluted in $10-20 \mathrm{ml}$ of standard assay buffer under agitation (170-300 rpm) for $2 \mathrm{~h}$ at room temperature $\left(18-24^{\circ} \mathrm{C}\right)$. The polyclonal antibodies used were directed against the amino acid sequence 132-164 of pre-pro-vasopressin. Then the test tubes were washed four times with $1 \mathrm{ml}$ of LUMI test wash solution, and bound chemoluminescence was measured for $1 \mathrm{~s}$ per tube with an LB952T Luminometer (Berthold, Wildbad, Germany).

Patients gave written informed consent for their participation. Ethics committee approved the study.

\section{Statistical analysis}

The data were analyzed with SPSS software (version 20; SPSS Inc., Chicago, Illinois, USA). The relationship between patients' characteristics and mortality was tested using a $\chi^{2}$ test in the univariate analysis. A $P$ value of less than 0.05 was considered to be statistically significant.

\section{Results}

A total of 60 patients were classified into four groups: control group comprised 15 apparently healthy nonsmoker patients, and asthma group comprised 45 patients with acute exacerbation of bronchial asthma (15 mild cases, 15 moderate cases, and 15 severe cases).

In the comparison between the cases and control group regarding age of the patient, it is apparent that mean \pm SD of the age was $44.27 \pm 9.92$ years in case group and years and $41.67 \pm 2.69$ years in control group, with nonsignificant difference $(P>0.05)$. Regarding sex, males represented $17.8 \%$ of the case group and $23.3 \%$ of the control group, and females represented $82.2 \%$ of the case group and $86.7 \%$ of the control group, with no significant difference between both the groups $(P>0.05)$. Mean \pm SD of BMI was $30.44 \pm 5.6$ in cases and $29.63 \pm 3.53$ in the control group. Student $t$ test showed nonsignificant difference in the BMI $(P>0.05)$ (Table 1, Fig. 1).

There was a statistically highly significant increase in pulmonary function tests in mild cases than moderate and severe cases $(P<0.001)$ (Table 2$)$.

There were statistically highly significant differences in partial pressure of oxygen in arterial blood $\left(\mathrm{PaO}_{2}\right)$ and saturated oxygen $\left(\mathrm{SaO}_{2}\right)$ among mild, moderate, and severe cases $(P<0.001)$ (Table 3, Fig. 2).

There was a statistically significant increase in total leukocytic count and hospital stay in severe cases than 
Table 1 Comparison between case and control groups regarding personal data

\begin{tabular}{|c|c|c|c|c|}
\hline & Case group (45) & Control group (15) & $t$ test & $P$ value \\
\hline \multicolumn{5}{|l|}{ Age } \\
\hline Mean \pm SD & $44.27 \pm 9.92$ & $41.67 \pm 2.69$ & 0.998 & 0.323 \\
\hline \multicolumn{5}{|l|}{ Sex } \\
\hline Male & $8(17.8)$ & 2 (13.3) & $\mathrm{FET}=0.0$ & 1.0 \\
\hline Female & $37(82.2)$ & $13(86.7)$ & & \\
\hline \multicolumn{5}{|l|}{ BMI } \\
\hline Mean \pm SD & $30.44 \pm 5.6$ & $29.63 \pm 3.53$ & 0.53 & 0.60 \\
\hline
\end{tabular}

Data are presented as mean \pm SD and $n(\%)$. FET, Fisher exact test. $P$ value obtained from analysis of variance test. Significance considered when $P$ value less than 0.05 . Nonsignificant difference $(P<0.05)$.

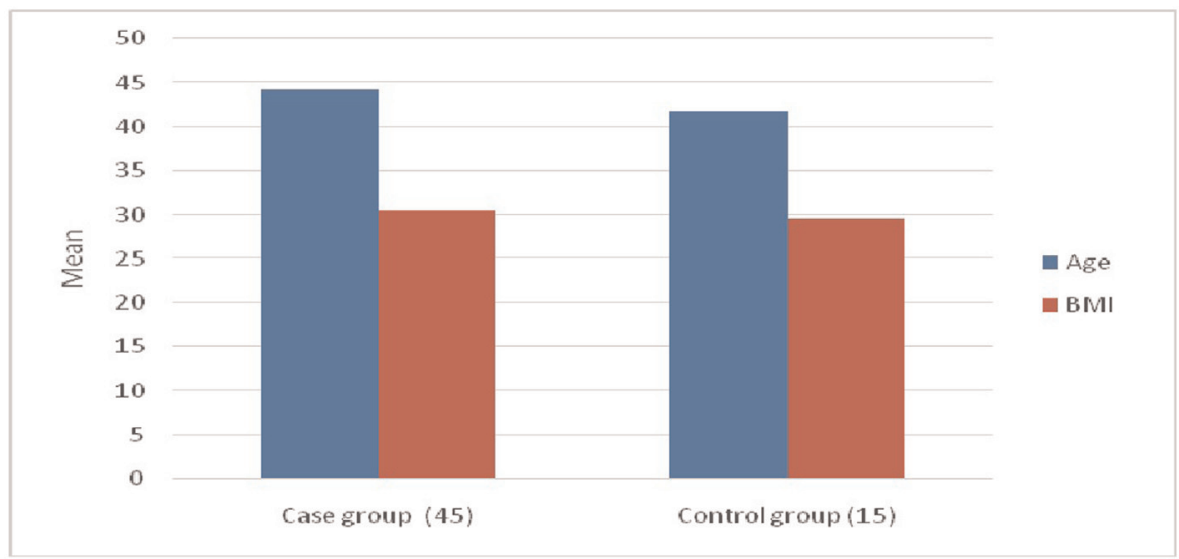

Comparison between case and control groups regarding age and BMI.

Table 2 Comparison between the studied groups according to pulmonary function tests

\begin{tabular}{lccccc}
\hline & $\begin{array}{c}\text { Mild } \\
\text { cases } \\
(15)\end{array}$ & $\begin{array}{c}\text { Moderate } \\
\text { cases (15) }\end{array}$ & $\begin{array}{c}\text { Severe } \\
\text { cases (15) }\end{array}$ & $\begin{array}{c}F \\
\text { test }\end{array}$ & $\begin{array}{c}P \\
\text { value }\end{array}$ \\
\hline FEV1 & 2.11 & $1.61 \pm 0.53$ & $0.94 \pm 0.36$ & 18.61 & 0.001 \\
actual & \pm 0.66 & & & & $(\mathrm{HS})$ \\
FEV1\% & 66.6 & $58.13 \pm 8.86$ & 35.8 & 29.83 & 0.001 \\
predicted & \pm 11.91 & & \pm 12.71 & & $(\mathrm{HS})$ \\
FVC\% & 79.67 & $68.87 \pm 8.35$ & 46.93 & 26.58 & 0.001 \\
predicted & \pm 9.95 & & \pm 17.39 & & $(\mathrm{HS})$ \\
PEF\% & 85.96 & $66.96 \pm 3.82$ & 32.18 & 269.4 & 0.001 \\
predicted & \pm 4.68 & & \pm 9.37 & & (HS) \\
\hline
\end{tabular}

FEV1, forced expiratory volume in $1 \mathrm{~s}$; FVC, forced vital capacity; HS, highly significant; PEF, peak expiratory flow. Significance considered when $P$ value less than 0.05 .

mild and moderate cases $(P<0.05)$ (Table 4, Fig. 3). The means $\pm \mathrm{SD}$ of plasma copeptin are $17.47 \pm 5.42$, $24.33 \pm 6.61,29.15 \pm 9.11$, and $6.31 \pm 1.46$ in mild cases, moderate case, severe cases, and controls. $F$ test shows highly significant increase of plasma copeptin in moderate and severe cases than mild cases and control group $(P<0.001)$ (Tables 5).

There was a significant negative correlation between forced expiratory volume in $1 \mathrm{~s}$ (FEV1) actual and copeptin in moderate cases $(P<0.05)$ (Table 7$)$.
Table 3 Comparison between the studied groups according to partial pressure of oxygen in arterial blood, partial pressure of carbon dioxide in arterial blood, and oxygen saturation

\begin{tabular}{|c|c|c|c|c|c|}
\hline & $\begin{array}{l}\text { Mild } \\
\text { cases } \\
(15)\end{array}$ & $\begin{array}{l}\text { Moderate } \\
\text { cases (15) }\end{array}$ & $\begin{array}{c}\text { Severe } \\
\text { cases (15) }\end{array}$ & $\begin{array}{c}F \\
\text { test }\end{array}$ & $\begin{array}{c}P \\
\text { value }\end{array}$ \\
\hline $\mathrm{PaO}_{2}$ & $\begin{array}{c}90.8 \\
\pm 2.26\end{array}$ & $65.99 \pm 3.8$ & $54.56 \pm 2.71$ & 574.8 & $0.001^{* *}$ \\
\hline $\mathrm{PaCO}_{2}$ & $\begin{array}{l}40.13 \\
\pm 1.85\end{array}$ & $41.79 \pm 7.07$ & $42.97 \pm 7.7$ & 0.82 & 0.45 \\
\hline $\mathrm{SaO}_{2}$ & $\begin{array}{l}97.69 \\
\pm 0.79\end{array}$ & $92.9 \pm 1.09$ & $86.54 \pm 1.75$ & 288.5 & $0.001^{* *}$ \\
\hline
\end{tabular}

$\mathrm{PaCO}_{2}$, partial pressure of carbon dioxide in arterial blood; $\mathrm{PaO}_{2}$, partial pressure of oxygen in arterial blood; $\mathrm{SaO}_{2}$, oxygen saturation. Significance considered when $P$ value less than 0.05 . **Highly significant.

There were significant negative correlations between copeptin and FEV1 actual, FEV1\% predicted, forced vital capacity $\%$ predicted, and peak expiratory flow $\%$ predicted in severe cases $(P<0.05)$ (Table 8$)$.

There were nonsignificant differences in copeptin levels between males and females in all groups $(P>0.05)$ (Table 9).

There were high significant negative correlations between copeptin and $\mathrm{PaO}_{2}$ and $\mathrm{SaO}_{2}$ in all cases 


\section{Figure 2}

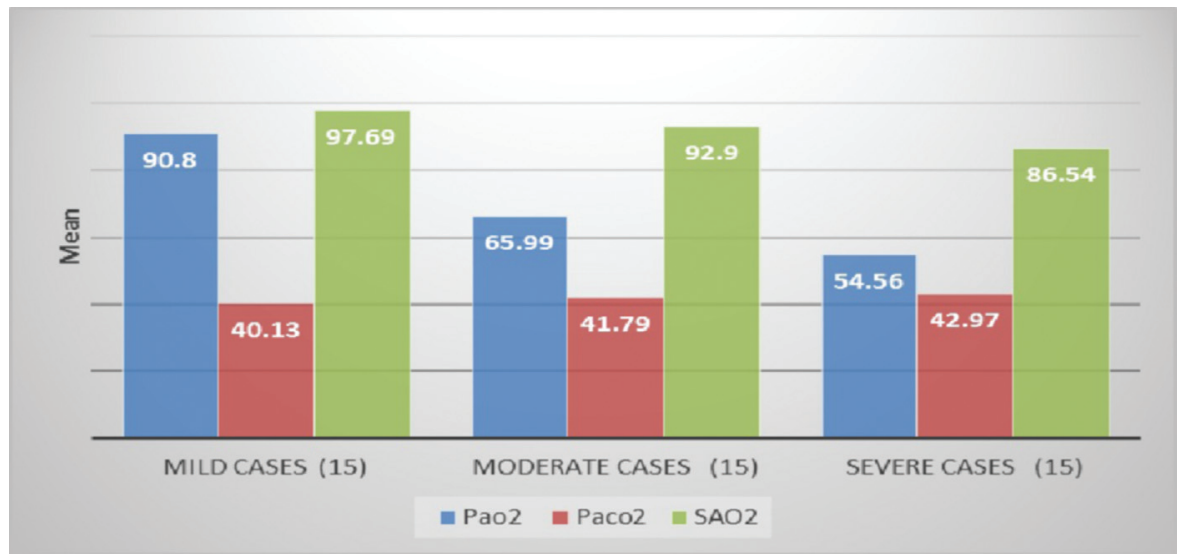

Comparison between the studied groups according to $\mathrm{PaO}_{2}, \mathrm{PaCO}_{2}$, and $\mathrm{SaO}_{2} . \mathrm{PaCO}_{2}$, partial pressure of carbon dioxide in arterial blood; $\mathrm{PaO}_{2}$, partial pressure of oxygen in arterial blood; $\mathrm{SaO}_{2}$, oxygen saturation.

Table 4 Comparison between the studied groups according to total leukocytic count and hospital stay

\begin{tabular}{|c|c|c|c|c|c|}
\hline & $\begin{array}{c}\text { Mild } \\
\text { cases } \\
(15)\end{array}$ & $\begin{array}{l}\text { Moderate } \\
\text { cases (15) }\end{array}$ & $\begin{array}{c}\text { Severe } \\
\text { cases } \\
(15)\end{array}$ & $F$ test & $\begin{array}{c}P \\
\text { value }\end{array}$ \\
\hline TLC & $\begin{array}{c}6786.67 \\
\pm 2453.24\end{array}$ & $\begin{array}{c}8053.33 \\
\pm 1453.99\end{array}$ & $\begin{array}{c}9133.33 \\
\pm 2107.02\end{array}$ & 4.94 & $\begin{array}{c}0.012 \\
(\mathrm{~S})\end{array}$ \\
\hline $\begin{array}{l}\text { Hospital } \\
\text { stay }\end{array}$ & $0.4 \pm 0.74$ & $1.13 \pm 1.19$ & $1.93 \pm 1.03$ & $\chi^{2}=12.98$ & $\begin{array}{c}0.002 \\
(\mathrm{~S})\end{array}$ \\
\hline
\end{tabular}

S, significant; TLC, total leukocyte count.

$(P<0.001)$, but $\mathrm{PaCO}_{2}$ exhibited a nonsignificant positive correlation with copeptin (Figs 4-7). $(P<0.05)$ (Table 10, Figs 8 and 9).

Copeptin level of $12.5 \mathrm{pg} / \mathrm{ml}$ predicts good prognosis and survival among patients with sensitivity of $97.8 \%$, specificity of $100 \%$, positive predictive value (PPV) of $100 \%$ and negative predictive value (NPV) of $93.8 \%$ with an accuracy of $98.3 \%$ and area under the curve (AUC) of 1 $(P<0.001)$ (Table 11).

Copeptin level of $12.5 \mathrm{pg} / \mathrm{ml}$ predicts good prognosis and survival among mild patients with sensitivity of 93.3\%, specificity of $100 \%$, PPV of $100 \%$, and NPV of $93.8 \%$, with an accuracy of $96.7 \%$ and AUC of 1 $(P<0.001)$ (Table 12).

Copeptin level of $16.6 \mathrm{pg} / \mathrm{ml}$ predicts good prognosis and survival among moderate patients with sensitivity of $86.7 \%$, specificity of $100 \%$, PPV of $100 \%$, and NPV of $88.2 \%$, with an accuracy of $93.3 \%$ and AUC of 1 $(P<0.001)$ (Table 13).

Copeptin level of $18.65 \mathrm{pg} / \mathrm{ml}$ predicts good prognosis and survival among severe patients with sensitivity of $86.7 \%$, specificity of $100 \%$, PPV of $100 \%$, and NPV of
$88.2 \%$, with an accuracy of $93.3 \%$ and AUC of 1 $(P<0.001)$ (Table 14).

\section{Discussion}

Arginine vasopressin is a posterior pituitary hormone that is synthesized in the hypothalamic periventricular and suprapotic nuclei and then is stored and released from the posterior pituitary gland as a result of certain stimuli, such as hypoxia, infections, hypotension, acidosis, and hyperosmolarity, and it is claimed to be a sensitive marker in these situations. Short half-life and instability of arginine vasopressin (AVP) caused limitations in its measurement. However, copeptin is more stable in plasma and serum. So it mirrors arginine vasopressin concentrations in individual stress response. Copeptin level has a marked increase when disease severity is increased, and in critically ill patients [5].

To evaluate patient's need for hospitalization and initiate a specific treatment, we need to know factors that predict a worse outcome in asthma. The use of biomarkers helps to estimate the presence of infections, their severity, and response to treatment. Copeptin can reflect both the inflammatory cytokine responses, which correlate with the severity of asthma, and the individual stress responses, and also the presence of hemodynamic and osmoregulatory disturbances. So, the aim of our study was to evaluate the role of copeptin in asthmatic patients and its relationship to disease severity.

Our study was carried out on 45 patients during acute exacerbation of bronchial asthma (15 mild cases, 15 moderate cases, and 15 severe cases) and 15 healthy participants. 


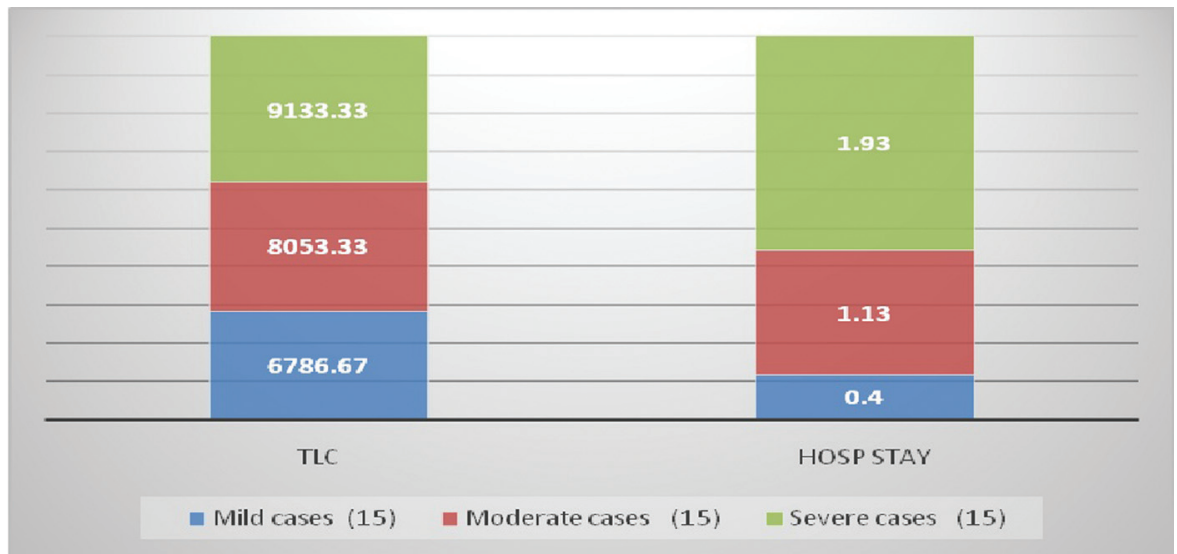

Comparison between the studied groups according to total leukocytic count and hospital stay.

Figure 4

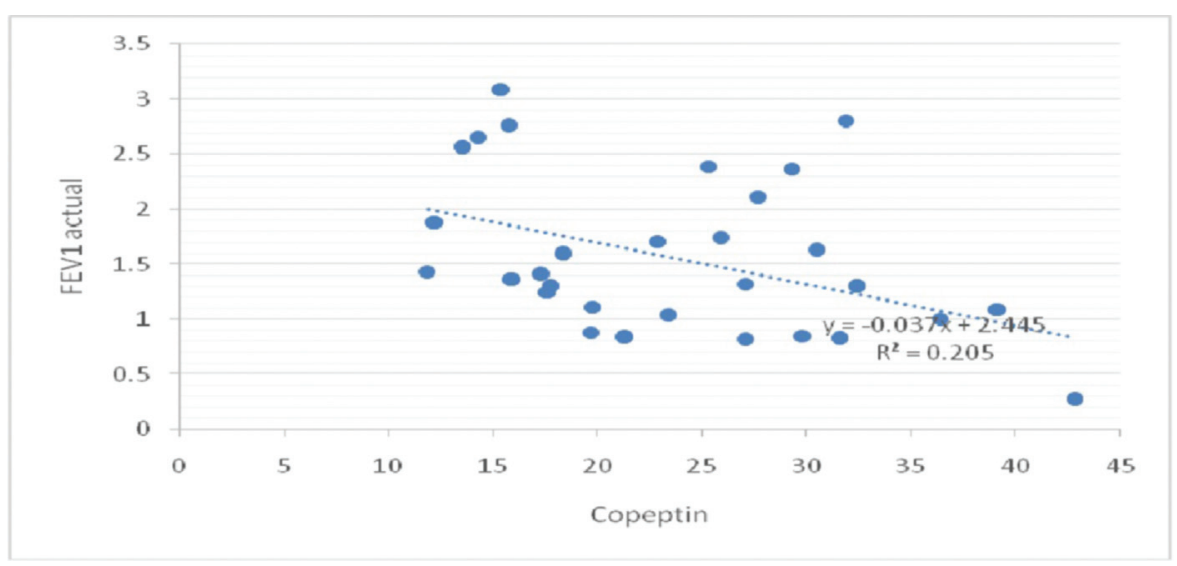

Correlation between copeptin and FEV1 actual among group of cases. FEV1, forced expiratory volume in $1 \mathrm{~s}$.

Figure 5

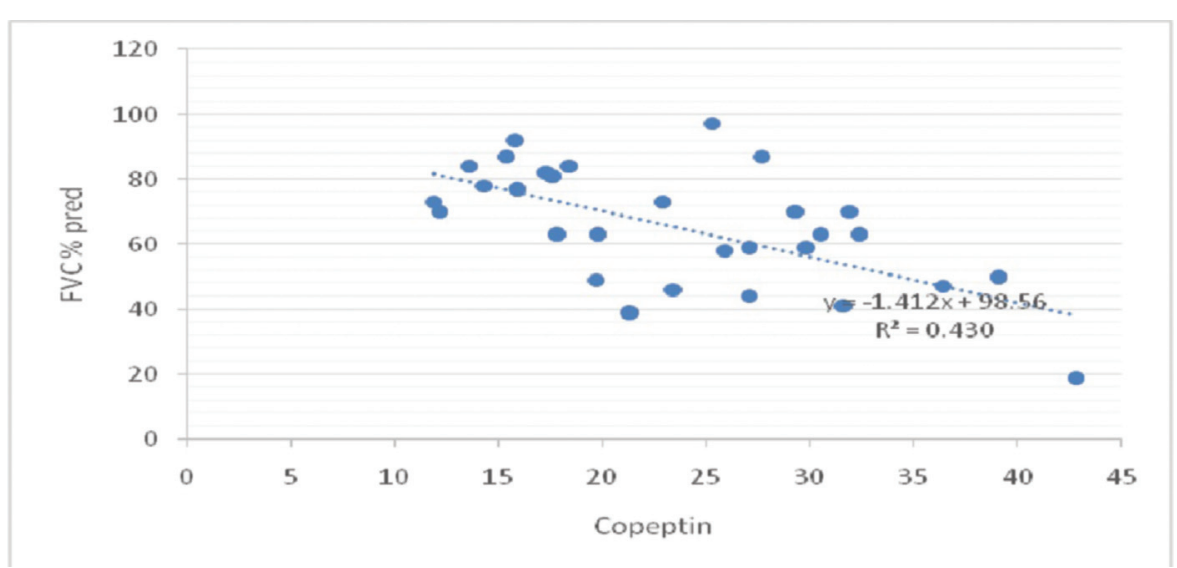

Correlation between copeptin and FVC\% predicted among group of cases. FVC, forced vital capacity. 


\section{Figure 6}

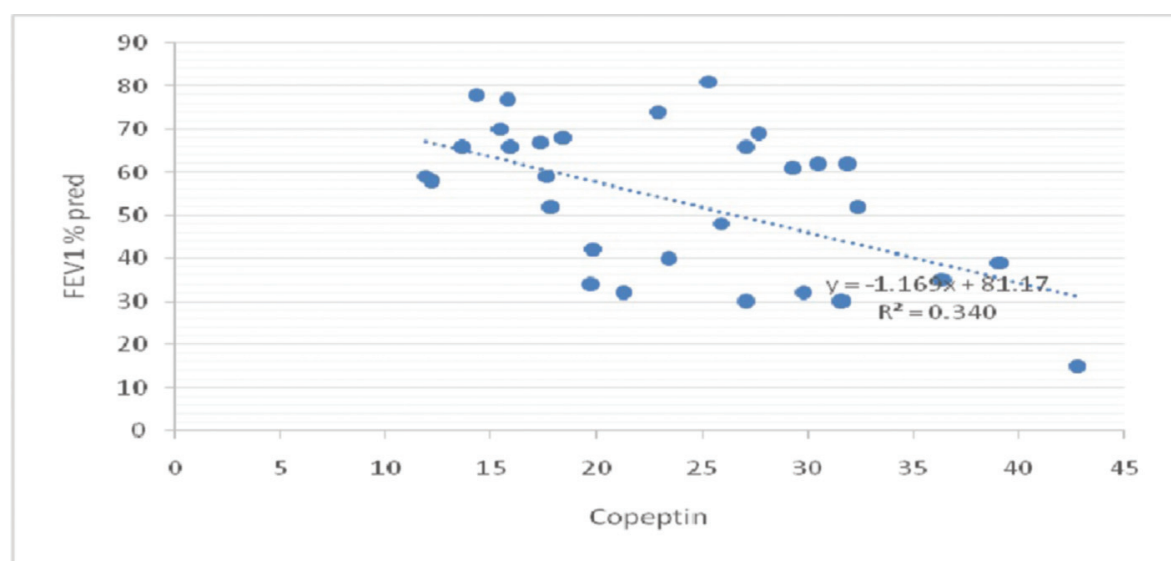

Correlation between copeptin and FEV1\% predicted among group of cases. FEV1, forced expiratory volume in $1 \mathrm{~s}$.

\section{Figure 7}

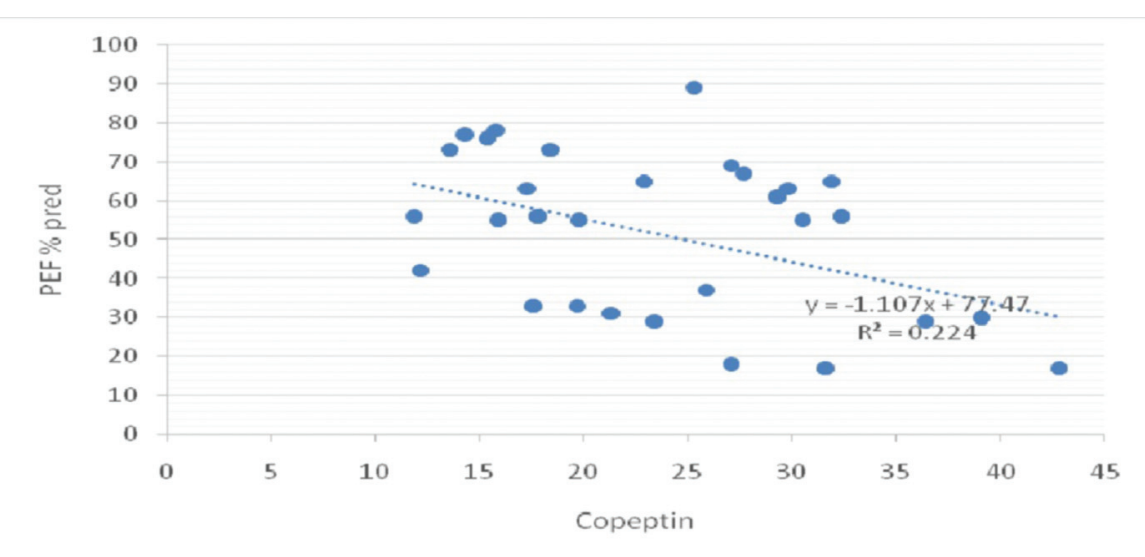

Correlation between copeptin and PEF\% predicted among group of cases. PEF, peak expiratory flow.

Table 5 Comparison between the studied groups according to copeptin value

\begin{tabular}{ccccccc}
\hline $\begin{array}{c}\text { Mild } \\
\text { cases } \\
(15)\end{array}$ & $\begin{array}{c}\text { Moderate } \\
\text { cases } \\
(15)\end{array}$ & $\begin{array}{c}\text { Severe } \\
\text { cases } \\
(15)\end{array}$ & $\begin{array}{c}\text { Control } \\
\text { group } \\
(15)\end{array}$ & $\begin{array}{c}F \\
\text { test }\end{array}$ & $\begin{array}{c}P \\
\text { value }\end{array}$ \\
\hline Copeptin & 17.47 & 24.33 & 29.15 & 6.31 & 37.21 & $0.001^{*}$ \\
& \pm 5.42 & \pm 6.61 & \pm 9.11 & \pm 1.46 & & \\
\hline
\end{tabular}

There was a nonsignificant correlation between copeptin and pulmonary function tests in mild cases $(P<0.05)$ (Table 6).

Table 6 Correlation between copeptin and pulmonary function tests in group of mild disease

\begin{tabular}{lcc}
\hline Copeptin & \multicolumn{2}{c}{ Mild cases (15) } \\
\cline { 2 - 3 } & $r$ & $P$ \\
\hline FEV1 actual & -0.40 & 0.09 (NS) \\
FEV1\% predicted & -0.18 & $0.53(\mathrm{NS})$ \\
FVC\% predicted & -0.16 & $0.56(\mathrm{NS})$ \\
PEF\% predicted & 0.31 & 0.27 (NS) \\
\hline
\end{tabular}

FEV1, forced expiratory volume in $1 \mathrm{~s}$; FVC, forced vital capacity; NS, nonsignificant; PEF, peak expiratory flow. Significance considered when $P$ value less than 0.05 .
Table 7 Correlation between copeptin and pulmonary function tests in moderate disease group

\begin{tabular}{lcc}
\hline Copeptin & \multicolumn{2}{c}{ Moderate cases (15) } \\
\cline { 2 - 3 } & $r$ & $P$ \\
\hline FEV1 actual & -0.54 & $0.036(\mathrm{~S})$ \\
FEV1\% predicted & 0.09 & $0.76(\mathrm{NS})$ \\
FVC\% predicted & -0.23 & $0.41(\mathrm{NS})$ \\
PEF\% predicted & 0.35 & $0.20(\mathrm{NS})$ \\
\hline
\end{tabular}

FEV1, forced expiratory volume in $1 \mathrm{~s}$; FVC, forced vital capacity; NS, nonsignificant; PEF, peak expiratory flow; S, significant. Significance considered when $P$ value less than 0.05 .

In the present study, mean $\pm \mathrm{SD}$ of the age was 44.27 \pm 9.92 years in case group and $41.67 \pm 2.69$ years in control group, with nonsignificant difference $(P>0.05)$.

Our results are in agreement with Morgenthaler et al. [6]. Their research assay measured copeptin level in serum and plasma of healthy individuals and patients to evaluate its clinical importance in a variety of 
pathologies in which arginine vasopressin secretion is reportedly disturbed, and they revealed that there was no major difference in median copeptin concentrations after stratification according to age groups.

Regarding sex, males represented $17.8 \%$ of case group and $23.3 \%$ of control group and females represented $82.2 \%$ of patient group and $86.7 \%$ of control group, with no significant difference between both groups $(P>0.05)$.

This study showed nonsignificant differences in copeptin levels between males and females in all groups $(P>0.05)$.

Table 8 Correlation between copeptin and pulmonary function tests in severe disease group

\begin{tabular}{lcc}
\hline Copeptin & \multicolumn{2}{c}{ Severe cases (15) } \\
\cline { 2 - 3 } & $r$ & $P$ \\
\hline FEV1 actual & -0.41 & $0.06(\mathrm{NS})$ \\
FEV1\% predicted & -0.65 & $0.009(\mathrm{~S})$ \\
FVC\% predicted & -0.65 & $0.009(\mathrm{~S})$ \\
PEF\% predicted & -0.57 & $0.03(\mathrm{~S})$ \\
\hline
\end{tabular}

FEV1, forced expiratory volume in $1 \mathrm{~s}$; FVC, forced vital capacity; NS, nonsignificant; PEF, peak expiratory flow. Significance considered when $P$ value less than 0.05 .

Table 9 Comparison of copeptin level between male and female in all groups

\begin{tabular}{lcccc}
\hline $\begin{array}{l}\text { Sex } \\
\text { (copeptin } \\
\text { levels) }\end{array}$ & $\begin{array}{c}\text { Mild } \\
\text { cases (15) } \\
(\text { mean } \\
\pm S D)\end{array}$ & $\begin{array}{c}\text { Moderate } \\
\text { cases (15) } \\
(\text { mean } \pm \text { SD) }\end{array}$ & $\begin{array}{c}\text { Severe } \\
\text { cases (15) } \\
(\text { mean } \pm S D)\end{array}$ & $\begin{array}{c}\text { Control } \\
\text { group (15) } \\
(\text { mean } \pm S D)\end{array}$ \\
\hline Male & $\begin{array}{c}14.46 \\
\pm 0.90\end{array}$ & $30.17 \pm 1.5$ & $\begin{array}{c}32.27 \\
\pm 13.10\end{array}$ & $8.2 \pm 0.85$ \\
Female & $\begin{array}{l}18.98 \\
\pm 6.15\end{array}$ & $22.87 \pm 6.6$ & $28.38 \pm 8.44$ & $6.02 \pm 1.31$ \\
& 1.61 & 1.85 & 0.65 & 2.24 \\
$t$ test & 0.133 & 0.09 & 0.53 & 0.083 \\
\hline value & &
\end{tabular}

Significance considered when $P$ value less than 0.05 . Highly significance considered when $P$ value less than 0.001 .
Our results were contrary to Bhandari et al. [7] who found that copeptin levels were significantly higher in healthy males than females $(P<0.001)$.

Pulmonary function tests showed highly statistically significant decrease in moderate and severe cases than mild cases $(P<0.001)$.

Ian and Fred [8] explained that airway inflammation occurs in both allergic and nonallergic forms of asthma and is a feature of all grades of asthma severity.

This study showed statistically highly significant differences in $\mathrm{PaO}_{2}$ and $\mathrm{SaO}_{2}$ among mild, moderate, and severe cases.

There was a significant increase in plasma copeptin, total leukocytic count, and hospital stay in severe and moderate cases than mild cases.

These results are in agreement with Al Salahy et al. [9], who found that elevated plasma copeptin levels reflect disease severity and predict long hospital and ICU stay.

Muller et al. [10] found that in patients with community acquired pneumonia (CAP), acute

Table 10 Correlation between copeptin and partial pressure of oxygen in arterial blood, partial pressure of carbon dioxide in arterial blood, and oxygen saturation

\begin{tabular}{lcc}
\hline Copeptin & \multicolumn{2}{c}{ Total cases (45) } \\
\cline { 2 - 3 } & $r$ & $P$ \\
\hline $\mathrm{PaO}_{2}$ & -0.62 & $0.001^{* *}$ \\
$\mathrm{PaCO}_{2}$ & 0.26 & 0.088 \\
$\mathrm{SaO}_{2}$ & -0.72 & $0.001^{* *}$
\end{tabular}

$\mathrm{PaCO}_{2}$, partial pressure of carbon dioxide in arterial blood; $\mathrm{PaO}_{2}$, partial pressure of oxygen in arterial blood; $\mathrm{SaO}_{2}$, oxygen saturation. Significance considered when $P$ value less than 0.05 . Highly significance considered when $P$ value less than 0.001 . **Highly significan.

Figure 8

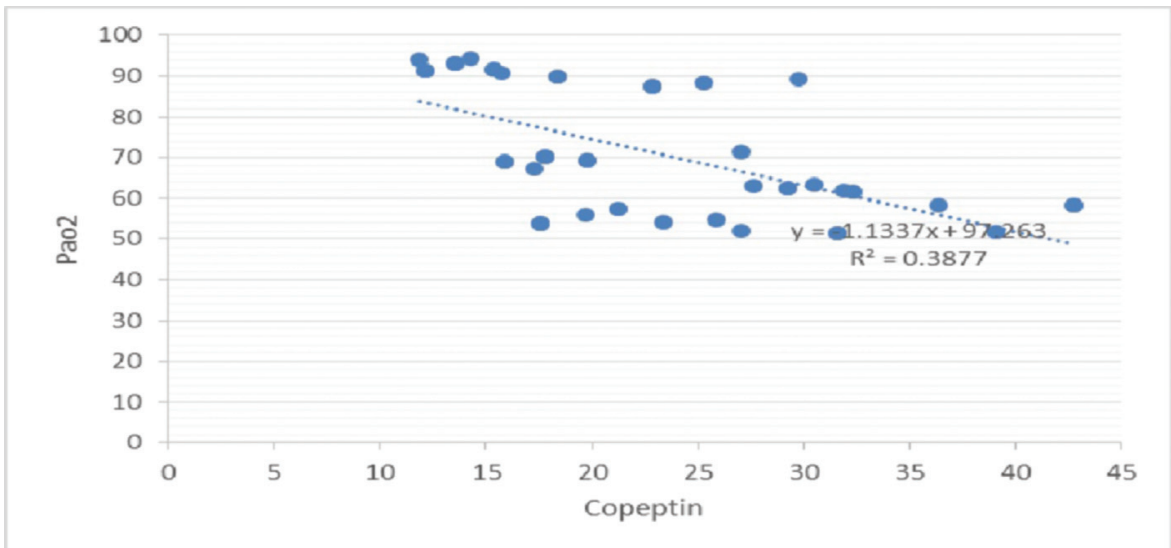




\section{Figure 9}

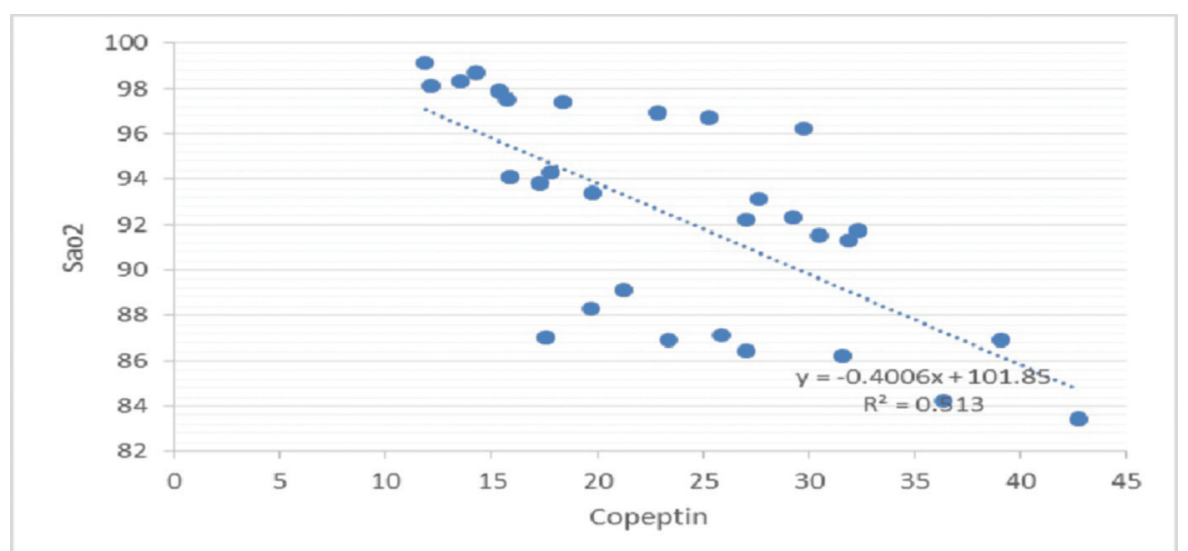

Correlation between copeptin and $\mathrm{SaO}_{2} . \mathrm{SaO}_{2}$, oxygen saturation.

Table 11 Validity of copeptin as a predictor of disease severity

\begin{tabular}{lcccc}
\hline Copeptin & Case group & Control group & FET & $P$ value \\
\hline$\geq 12.05$ & $44(97.8)$ & $0(0.0)$ & 50.11 & $0.001^{\text {** }}$ \\
$<12.05$ & $1(2.2)$ & $15(100)$ & & \\
AUC & & 1.0 & & \\
Cutoff point & & 12.05 & & \\
Sensitivity & & 97.8 & & \\
Specificity & & 100 & & \\
PPV & & 100 & & \\
NPV & & 93.8 & & \\
Accuracy & & 98.3 & \\
\hline
\end{tabular}

AUC, area under the curve; FET, Fisher exact test; NPV, negative predictive value; PPV, positive predictive value. ${ }^{*}$ Highly significan.

Table 12 Validity of copeptin as a predictor of disease severity among patients with mild bronchial asthma

\begin{tabular}{lcccc}
\hline Copeptin & $\begin{array}{c}\text { Mild group } \\
(15)\end{array}$ & $\begin{array}{c}\text { Control group } \\
(15)\end{array}$ & $\chi^{2}$ & $\begin{array}{c}P \\
\text { value }\end{array}$ \\
\hline$\geq 12.05$ & $14(93.3)$ & $0(0.0)$ & 22.63 & $0.001^{* *}$ \\
$<12.05$ & $1(6.7)$ & $15(100)$ & & \\
AUC & & 1.0 & & \\
Cutoff & & 12.05 & & \\
point & & & & \\
Sensitivity & & 93.3 & & \\
Specificity & & 100 & & \\
PPV & & 100 & & \\
NPV & & 93.8 & \\
Accuracy & & 96.7 & \\
\hline AUC, and & &
\end{tabular}

AUC, and area under the curve; NPV, negative predictive value; PPV, positive predictive value. ${ }^{\star *}$ Highly significan.

exacerbation of chronic obstructive pulmonary disease (AECOPD), and exacerbation of asthma, copeptin levels were also significantly higher as compared with controls $(P<0.001)$.

Xue et al. [3] evaluated theutilityof copeptin as a prognostic marker in 525 patients with acute dyspnea owing to asthma, COPD, pneumonia, bronchitis, and influenza.
Table 13 Validity of copeptin as a predictor of disease among patients with moderate bronchial asthma

\begin{tabular}{lcccc}
\hline Copeptin & $\begin{array}{c}\text { Moderate group } \\
(15)\end{array}$ & $\begin{array}{c}\text { Control group } \\
(15)\end{array}$ & $\chi^{2}$ & $\begin{array}{c}P \\
\text { value }\end{array}$ \\
\hline$\geq 16.6$ & $13(86.7)$ & $0(0.0)$ & 22.94 & $0.001^{\text {** }}$ \\
$<16.6$ & $2(13.3)$ & $15(100)$ & & \\
AUC & & 1.0 & & \\
Cutoff & & 16.6 & & \\
point & & & & \\
Sensitivity & & 86.7 & & \\
Specificity & & 100 & & \\
PPV & & 100 & \\
NPV & & 88.2 & \\
Accuracy & & 93.3 & \\
\hline
\end{tabular}

AUC, and area under the curve; NPV, negative predictive value; PPV, positive predictive value. ${ }^{* *}$ Highly significan.

Table 14 Validity of copeptin as a predictor of disease among patients with severe bronchial asthma

\begin{tabular}{lcccc}
\hline Copeptin & $\begin{array}{c}\text { Severe group } \\
(15)\end{array}$ & $\begin{array}{c}\text { Control group } \\
(15)\end{array}$ & $\chi^{2}$ & $\begin{array}{c}P \\
\text { value }\end{array}$ \\
\hline$\geq 18.65$ & $13(86.7)$ & $0(0.0)$ & 22.94 & $0.001^{\text {** }}$ \\
$<18.65$ & $2(13.3)$ & $15(100)$ & & \\
AUC & & 1.0 & & \\
Cutoff & & 18.65 & & \\
point & & & & \\
Sensitivity & & 86.7 & & \\
Specificity & & 100 & & \\
PPV & & 100 & & \\
NPV & & 88.2 & & \\
Accuracy & & 93.3 & & \\
\hline
\end{tabular}

AUC, and area under the curve; NPV, negative predictive value; PPV, positive predictive value. ${ }^{* *}$ Highly significan.

They concluded that copeptin is a significant independent predictor of increased hospital stay and mortality in patients with acute dyspnea of noncardiac origin.

There were highly significant negative correlations between copeptin and $\mathrm{PaO}_{2}$ and $\mathrm{SaO}_{2}$ in all cases 
$(P<0.001)$, but $\mathrm{PaCO}_{2}$ exhibited a nonsignifican positive correlation with copeptin $(P<0.05)$.

These results are in agreement with Al Salahy et al. [9], who found that copeptin concentrations are strongly related to hypoxia, as they increase markedly with low blood oxygen concentration.

Many studies were conducted to reveal the correlation between hypoxia as a stress factor and serum copeptin levels, which was statistically significant and positive in most of cases.

In one of the early studies on the relation between copeptin and hypoxia, Akagi et al. [11] obtained the same results by finding a relationship between the hormonal response to acute hypoxemia in fetal sheep and arterial blood gases values.

Our results are supported by those of Ostergaard et al. [12] on measuring plasma levels of copeptin of Sprague-Dawley rats under normoxic conditions and after acute exposure to $10 \%$ oxygen for $5 \mathrm{~min}$. They showed seven-fold increase in level of plasma copeptin. So, plasma copeptin is considered a sensitive, strong marker on exposure to acute severe hypoxia.

Moreover, Schlapbach et al. [13] measured copeptin level in blood of umbilical cord of infants with chorioamnionitis, perinatal asphyxia, and early-onset sepsis. They found that the highest copeptin concentrations among all three stressor factors were in neonates who have asphyxia when compared with controls. These results were confirmed by multivariate analysis adjusted for birth weight, gestational age, mode of delivery, and umbilical artery. RoC curve analysis showed that concentrations of copeptin in blood cord have a strong association with asphyxia.

\section{Conclusion}

From this study, it can be concluded that copeptin levels can be a tool for the risk stratification in patients with bronchial asthma as compared with healthy controls. Copeptin is secreted in blood in an equimolar ratio to AVP and is more reliable to assay. Copeptin has been utilized as a surrogate marker of AVP activity in recent investigations.

\section{Financial support and sponsorship}

Nil.

\section{Conflicts of interest}

There are no conflicts of interest.

\section{References}

1 Hiroyuki T, Ishioka T, Noda M. Molecular epidemiology of respiratory viruses in virus-induced asthma. Front Microbiol 2013; 4:278.

2 Morgenthaler N, Struck J, Jochberger S. Copeptin: clinical use of a new biomarker. Trends Endocrinol Metab 2008; 19:43-49.

3 Xue Y, Tong J, Clopton P. Elevated copeptin is associated with increased 90 day mortality in patients with acute dyspnea from non-cardiac causes: Secondary results from the BACH study. JACC 2012; 59:E945.

4 Global Initiative for Asthma. Global strategy for asthma management and prevention. 2016. Available at: www.ginasthma.org. [Accessed June 9 , 2018]

5 Morgenthaler NG, Muller B, Struck J, Bergmann A, Redl H, ChristCrain M. Copeptin, a stable peptide of the arginine vasopressin precursor, is elevated in hemorrhagic and septic shock. Shock 2007; 28:219-226.

6 Morgenthaler NG, Struck J, Alonso C, Bergmann A. Assay for the measurement of copeptin, a stable peptide derived from the precurso of vasopressin. endocrinology and metabolism. Clin Chem 2006 52:112-119.

7 Bhandari SS, Loke I, Davies JE, Squire IB, Struck J, Ng LL. Gender and renal function influence plasma levels of copeptin in healthy individuals. Clin Sci J 2009; 116:257-263.

8 lan RM, Fred SR. Allergy and allergic diseases (review articles). N Engl Med 2001; 344:109-113.

9 Al Salahy MM, Elmahdya MA, Goudaa TM, Belalb KM, Elnahasa SM. Study of plasma copeptin level as a prognostic marker in respiratory failure patients admitted in the ICU. Egypt J Bronchol 2018; 12:200-207.

10 Muller B, Morgenthaler N, Stolz D. Circulating levels of copeptin, a novel biomarker, in lower respiratory tract infections. Eur J Clin Invest 2007; 37:145-152.

11 Akagi K, Berdusco ET, Challis JR. Cortisol inhibits ACTH but not the AVP response to hypoxaemia in fetal lambs at days 123-128 of gestation. J Dev Physiol 1990; 14:319-324.

12 Ostergaard L, Rrudiger A, Wellmann S, Gammella E, Beck-schimmer B, Struck J, et al. Arginine-vasopressin marker copeptin is a sensitive plasma surrogate of hypoxic exposure. Hypoxia (Auckl) 2014 2:143-151.

13 Schlapbach LJ, Frey S, Bigler S, Manh-Nhi C, Aebi C, Nelle M, et al. Copeptin concentration in cord blood in infants with early-onset sepsis, chorioamnionitis and perinatal asphyxia. BMC Pediatrics 2011; 11:38. 